\title{
The Role of Principals in Children's Literacy Culture for Elementary School
}

\author{
Eva Tri Rusdyaningtyas ${ }^{1}$ and Farida Hanum ${ }^{2}$ \\ \{evatrt.2017@student.uny.ac.id ${ }^{1}, \&$ faridahanum@uny.ac.id $\left.{ }^{2}\right\}$ \\ 1,2Universitas Negeri Yogyakarta, Indonesia
}

\begin{abstract}
The ability of childbirth from an early age needs to be done by the Special Family Environment of both parents. However, not all parents are able to get used to reading from an early age. In Banyumas Regency, Indonesian, parents / guardians of students provide accountability for the ability to read and write on the part of the school. This research aimed to describe study the role of principals in literacy culture in elementary schools. The research method used is a qualitative research method using phenomenology. Data analysis was carried out by field observations and interviews with principals and teachers. The results obtained by carrying out this research were principals who collected important information in the children's literacy culture at school. Based on the field survey, the school principal cooperates with the teacher in the class to encourage students to want to and get used to reading and making written works. Students can make short stories and poems in accordance with the abilities of students.
\end{abstract}

Keywords: children's literacy, culture of literacy, role of principals

\section{INTRODUCTION}

Education when facing a critical challenge, namely child literacy education in the face of increasingly advanced digital culture [1]. Therefore, this challenge needs to be addressed by encouraging children to have an interest in reading and can choose the right information. Interest in children's reading can occur first from the family environment [2]. If both parents support and familiarize early on, parents have an interest in reading at home and in the school environment. The basic skills that need to be developed by children are reading and writing. Taking the perspective of Andalusian families in practice in the family environment, they are not aware of their role in literacy efforts by their children, as a result families often do not pay attention to various literacy cultures especially in literacy practices at home [3]. Literacy activities are related to reading and writing activities. Reading is a person's mental process or effective learning activities for a person to be able to improve his ability to think critically, develop new and different perspectives, and be able to interpret events and situations to be faced [4]. Knowledge and understanding of reading skills is one of the most important and most significant academic tasks performed by students during elementary school [5]. In addition, support from teachers and principals, facilities at the school also determine the child to be able to like reading books. Support from parents can be in the form of providing reading books at 
home according to the needs and characteristics of children, such as storytelling books (tales), and books that are liked.

The principal needs to have a strategy in managing activities and activities carried out by the school. However, establishing a decision to carry out activities in accordance with planned procedures is not an easy matter to implement [6]. As happened in the African and American environment, based on research for literacy activities there needs to be a solid relationship between family and teachers, this happens so that the teacher knows the family condition of each environment and seeks to analyze and determine strategies for practicing literacy culture in school [7]. The most important indicator in the early development of students in elementary school is children's reading ability [8]. Reading and writing activities can be regarded as literacy activities. Literacy is the ability to process information and knowledge as a basis for everyday skills. Basic skills in literacy, will be used by someone in basic education for life. Behavior of children at an early age needs special attention in an effort to improve achievement, therefore support from the school environment and family plays an important role in literacy activities [9]. If the family environment supports literacy activities, then the child begins to be interested and accustomed to reading and writing. Literacy activities are currently applied in schools because this activity contributes in several ways that regulate how children can obtain new vocabulary in language and communicate with their social environment [10]. Habituation and formation of related information about information literacy, information culture, and media literacy in Russia, like other countries in the world that have been implemented for years [11]. Basically a culture of literacy especially in children if applied continuously will increase their reading interest.

\section{METHOD}

This study uses descriptive qualitative data collection techniques and interviews and observations in one of the elementary schools in Banyumas Regency. The use of this method is to describe the role of the school principal in child literacy habituation activities in elementary school. The interviewees who denied this research were principals and classroom teachers as sources of information for data collection activities. In addition, observations are carried out when literacy activities take place. Literacy activities at this school were carried out during the last study hours. The students observed are second class. Literacy activities are carried out at the last lesson with the reason that students in the discussion are not saturated with learning activities at the end. In addition, the concept of literacy activities is also carried out in the library.

\section{RESULT AND DISCUSSION}

Principals and teachers participate in literacy culture in schools by reading books that suit their interests. For example, reading religious books, health, lessons, and novels. The principal and teacher are examples of students, so they participate in carrying out these activities. The culture of literacy carried out at each school is different. One of the schools in Banyumas Regency has its own characteristics in applying its literacy power. The school principal coordinates with the teacher that the literacy culture is adjusted to the teacher in the class. The systematics of the principal in coordinating can be presented in the figure as follows.

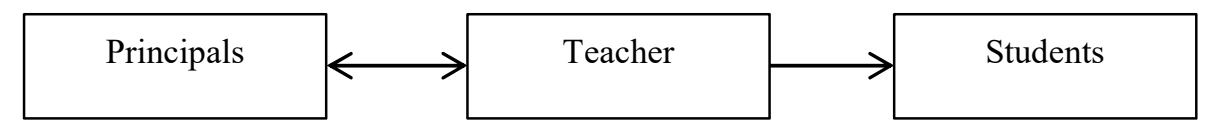


Information:

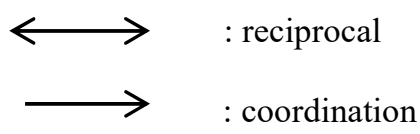

The reciprocal lines above illustrate that there is cooperation between the principal and the class teacher and means that after the culture of literacy is carried out if it has obstacles in its implementation, the class teacher provides a report on matters relating to these constraints. Then the line of coordination between class teachers and students has the understanding that the class teacher as a supervisor and informant related to the implementation of literacy in the classroom. The concept of literacy culture in one school in Banyumas Regency is that each class has its own schedule for literacy. This activity was carried out in the school library on the grounds that if carried out in the classroom children are easily bored and more likely to play. For example literacy culture at the second grade of elementary school is held on Thursday, 11:15 am when learning has finished.

\subsection{Principal as Supporting Literacy of Children in Schools}

As leaders, principals have an important role in children's literacy culture especially in elementary schools. One of the supports from the principal is facilitating students with complete books in the library, book updates, and wall magazine corners. In addition, the principal provides information to students through the ceremony that literacy activities are very important to increase students' insight.

The principal and teacher when the meeting coordinates the strategies that really need to be done so that the child has an interest in reading especially for the first to third graders of elementary school. The class teacher has a strategy of changing the method of activity, namely students are asked to read on their own, and read aloud by the class teacher. Even when the principal is given questions about the effectiveness of this literacy activity, the principal answers;

"Yes, very effective. It even helps for first and second graders who can't read well. Indeed, there needs to be supervision and perseverance from each class teacher. I always coordinate with the teacher and ask how far the interest in reading students is until now."

Then, the principal explained the positive impact on literacy activities in elementary schools. This impact is experienced when learning in class. Teacher convey that children are more active and their curiosity is higher than before.

"The vocabulary of children is increasing, especially when I teach in the second grade.

Children are enthusiastic during literacy hours, because children are allowed to choose

books in the library, which is currently increasing."

Literacy activities with reading and writing are one of the efforts to improve the information literacy culture. The reason is because with the presence of literacy activities in schools, especially children, they will get new information, especially books that children read not only in textbooks but other scientific books. Based on interviews with school principals and classroom teachers there are several impacts that are felt for the application of this literacy activity. The following will be described through the table. 
Table 1 Analysis of Application of Literacy Activities in Elementary Schools

\begin{tabular}{ccccc}
\hline & \multicolumn{2}{c}{ Positive Impact of Literacy Activities } & Weaknesses of Literacy Activities \\
\cline { 2 - 4 } & 1. $\begin{array}{l}\text { Generating interest in reading for } \\
\text { children, for example with picture } \\
\text { books so that children are willing } \\
\text { to read. }\end{array}$ & $\begin{array}{l}\text { Some books that have been available } \\
\text { are lost because the borrowing of } \\
\text { students is not returned }\end{array}$ \\
Activities & 2. $\begin{array}{l}\text { Helping teachers in the learning } \\
\text { process, especially Indonesian, so } \\
\text { students can read more smoothly } \\
\text { Children can take the core story on } \\
\text { the sentence in the book they have } \\
\text { read. }\end{array}$ & $\begin{array}{l}\text { Lack of supervision in borrowing } \\
\text { books in the library or in the } \\
\text { classroom } \\
\text { Students get bored easily }\end{array}$ \\
\hline
\end{tabular}

Table 1, it is explained that the application of literacy culture in elementary schools has a positive impact that has the benefit of increasing interest in reading children in school. In addition to positive effects and weaknesses, another finding related to this application is that leadership carried out by principals uses transformational leadership models. Principals make efforts to improve the quality of teachers in schools, utilize existing resources and optimize the performance of teachers. In connection with the interview, the principal stated that every time there were obstacles and problems in literacy activities and other activities, the principal had a chat with the teachers about the problems that occurred and determined ways to overcome these problems. So that the teacher is involved directly in the decision to resolve a problem that occurs in the school environment.

\subsection{Children's Literacy Culture in Elementary Schools}

Reading and writing activities can be regarded as literacy activities. Literacy is the ability to process information and knowledge as a basis for everyday skills. Basic skills in literacy, will be used by someone in basic education for life. Implementation in school, the teacher as one of the observers of the development of students has a high responsibility to ensure that these basic skills can be obtained effectively students begin to have an interest in reading [12]. The following is one of the literacy cultures in one of the Banyumas Regency Elementary Schools.

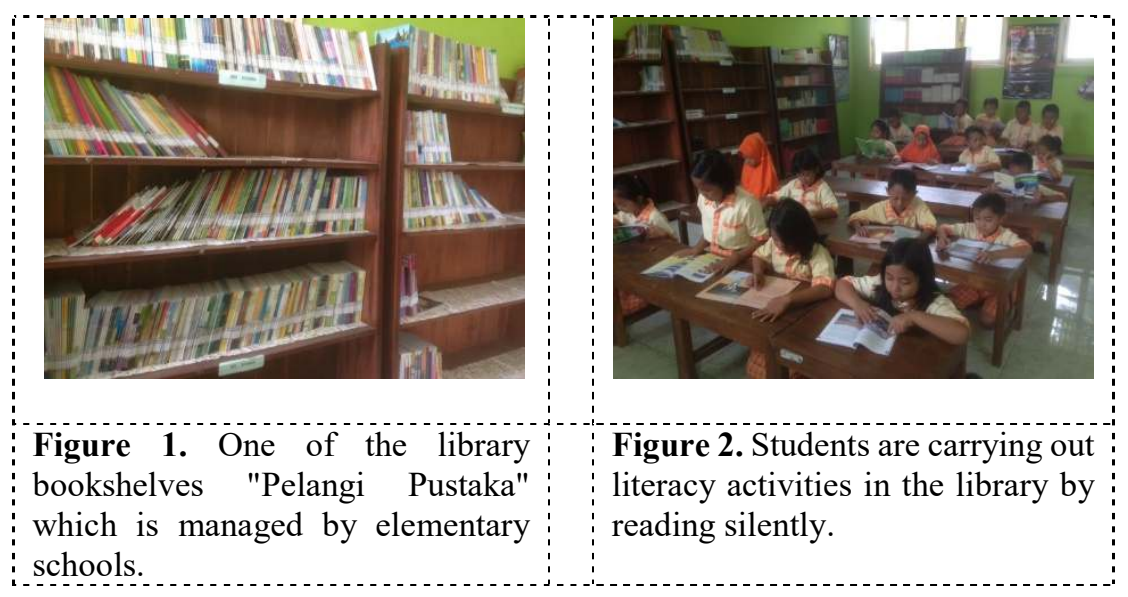


Based on the survey, students in this elementary school were enthusiastic about the literacy culture that was applied in the school. One example can be seen in Figure 2. Figure 2 explains that children have a reading interest in school. Literacy culture does require perseverance and patience in carrying out it. If done consistently, it will get a positive impact from the implementation of this activity. Collaboration between school principals and teachers and school residents. Even this activity proves clearly that literacy has positive learning to encourage students to improve their abilities both in academic and non-academic.

\section{CONCLUSION}

The habit of literacy culture especially in children in elementary school is one of the efforts to increase children's reading interest. Principals have an important role in the success of activities in schools, especially literacy activities. Policy and cooperation between principals and teachers for student discipline in reading has a positive impact on students. It is not easy to give understanding to students in elementary school about the importance of reading books. However, the discipline and perseverance carried out by the principal and the teacher will reap the rewards. As in the statement in the findings, that students have better language skills than before. Students can determine the core story of the book they have read. Class teachers need to have a strategy in increasing children's reading interest in literacy culture at school. Strategies that can be done, such as storytelling, involve children in learning written languages (writing stories), because stories can make the learning process of literacy more meaningful, especially accompanied by assistive media such as dolls in storytelling so that children can enjoy stories and easily understand the statement [13]. Then another strategy for the role of principals and teachers in the dissemination of each flag ceremony is one of the factors that attempts to make students aware of reading. But basically more research is needed to explore the factors that encourage interest in reading and writing in school [14]. In addition, the importance of literacy efforts for human resource development occurs in several countries, one of them being Malaysia. This is done because of the impact of sustainable globalization on the country's future and welfare [15]. Therefore, child literacy education needs to be done early so that an increasingly advanced era can be utilized by the next generation for its survival.

\section{REFERENCE}

[1] A. P. Vélez and I. I. Zuazua, "Digital Literacy and Cyberconvivencia in Elementary Education,” Procedia - Soc. Behav. Sci., vol. 237, no. June 2016, pp. 110-117, 2017.

[2] J. P. Pezoa, S. Mendive, and K. Strasser, "Reading interest and family literacy practices from prekindergarten to kindergarten: Contributions from a cross-lagged analysis," Early Child. Res. Q., vol. 47, pp. 284-295, 2019.

[3] C. Moreno-Morilla, F. Guzmán-Simón, and E. García-Jiménez, "Literacy practices of elementary education children in Andalusia (Spain): A family-based perspective," $\mathrm{Br}$. Educ. Res. J., vol. 45, no. 1, pp. 117-136, 2019.

[4] A. Karadeniz and R. Can, "A Research on Book Reading Habits and Media Literacy of Students at the Faculty of Education," Procedia - Soc. Behav. Sci., vol. 174, pp. 4058 4067, 2015.

[5] B. R. Walgermo, J. C. Frijters, and O. J. Solheim, "Literacy interest and reader selfconcept when formal reading instruction begins," Early Child. Res. Q., vol. 44, pp. 90100,2018 .

[6] D. Olcum and O. Titrek, “The Effect of School Administrators' Decision-Making Styles 
on Teacher Job Satisfaction," Procedia - Soc. Behav. Sci., vol. 197, no. February, pp. 1936-1946, 2015.

[7] T. L. Ellison, "Counter-Storytelling vs . Deficit Thinking around African American Children and Families, Digital Literacies , Race, and the Digital Divide CounterStorytelling," vol. 53, no. 3, pp. 223-244, 2019.

[8] C. Varghese, L. Vernon-Feagans, and M. Bratsch-Hines, "Associations between teacherchild relationships, children's literacy achievement, and social competencies for struggling and non-struggling readers in early elementary school," Early Child. Res. Q., vol. 47, pp. 124-133, 2019.

[9] D. Stipek, S. Newton, and A. Chudgar, "Learning-related behaviors and literacy achievement in elementary school-aged children," Early Child. Res. Q., vol. 25, no. 3, pp. $385-395,2010$.

[10] H. P. Laursen and L. Fabrin, “Children investing in literacy," Linguist. Educ., vol. 24, no. 4, pp. 441-453, 2013.

[11] N. Gendina, Information Culture and Information Literacy as a Scientific Direction and a Field of Educational Activities in Russia. Elsevier Ltd, 2016.

[12] A. H. Ulaş, C. Epçaçan, and B. Koçak, "Opinions of teacher candidates on elementary literacy teaching," Procedia - Soc. Behav. Sci., vol. 31, no. 2011, pp. 383-390, 2012.

[13] L. Flórez-Aristizábal, S. Cano, C. A. Collazos, F. Benavides, F. Moreira, and H. M. Fardoun, "Digital transformation to support literacy teaching to deaf Children: From storytelling to digital interactive storytelling," Telemat. Informatics, vol. 38, pp. 87-99, 2019.

[14] J. M. Carroll, A. J. Holliman, F. Weir, and A. E. Baroody, "Literacy interest, home literacy environment and emergent literacy skills in preschoolers," J. Res. Read., vol. 42, no. 1, pp. $150-161,2019$.

[15] F. P. Chew, "Literacy among the Secondary Schools Students in Malaysia," Int. J. Soc. Sci. Humanit., no. January 2013, pp. 546-550, 2013. 